\title{
Epitomising Public Sector Management of Public Private Partnerships: A Trajectory of Good Governance
}

\author{
Jude Thaddeo Mugarura ${ }^{1} \&$ Zwelinzima Ndevu $^{2}$ \\ ${ }^{1}$ Department of Marketing and Management, Makerere University, Kampala, Uganda \\ ${ }^{2}$ School of Public Leadership, Stellenbosch University, Matieland, South Africa \\ Correspondence: Jude Thaddeo Mugarura, Department of Marketing and Management, Makerere University, \\ Kampala, Uganda. E-mail: mugarurajude@yahoo.com
}

\author{
Received: January 20, 2020 Accepted: September 5, 2020 Online Published: October 13, 2020 \\ doi:10.5539/par.v9n2p38 URL: http://dx.doi.org/10.5539/par.v9n2p38
}

\begin{abstract}
While research and policy documents seem to equate public private partnerships (PPPs) to a "marriage made in heaven", globally they have had flimsy impact on public service delivery. Such seem to be caused by myopic governance emanating from scattered PPP governance literature, lack of a clear PPP good governance overview, as well as overemphasis of PPP financing over the wider PPP governance aspects. Using scholarly documents through content analysis, this study therefore intended to identify and examine the elements of a PPP governance system, and thereafter provide strategies of enforcing good governance practices for PPPs to serve their intended purpose. Findings indicate that PPP principles, critical success factors, stakeholder and risk management, and management of PPP maturity trends, make up a PPP good governance system. Finally, for each of the findings established, the study proposes appropriate good governance practices for sustainable PPP interventions.
\end{abstract}

Keywords: public private partnership, good governance system, key elements, strategies

\section{Introduction}

Governments make appealing policy promises when embracing public private partnerships as a model of public service delivery (Eggers \& Startup, 2006). According to Casady, Eriksson, Levitt and Scott (2019) PPPs are long term contractual engagements between the public, private and third sector institutions that encourage greater private participation and risk sharing during the overall infrastructure/service project lifespan (Casady, Eriksson, Levitt \& Scott, 2019). The single most PPP motivation for governments rests in private sector financing and direct user fees to develop and pay for the operation of public infrastructure (World Bank Group, 2012). While such enables public facilities to be constructed and services consumed earlier than later, according to Siemiatycki (2013) as time goes by, PPP impetuses evolve and become numerous.

Surprisingly, literature on PPP governance remains scattered and with less clarity (Silva \& Schaltegger, 2019), and this prompts governments to overemphasize the financing objective over the wider PPP governance aspects (Organisation for Economic Co-operation and Development-OECD, 2015, p.1). As such, unless scholars take a step forward to provide guidance on how PPP arrangements have to be governed, PPP performance will remain compromisable and unsustainable (Willems, Van Dooren \& Van den Hurk, 2017, p.466). Drawing from the United Nations Development Programme-UNDP (as cited in Rondinelli, 2007, p.7) this study defines PPP good governance as, the widespread participation, rule of law, institutional transparency, responsiveness to society needs, equal treatment of people, right usage of public resources, public accountability, and strategically planning for development through PPP arrangements.

Essentially, the success of PPP projects is dependent on the public, private and third sectors having transparent and accountable institutions with competent and skilled employees that are willing to do the right things in the right way. Given that good governance plays a decisive role in PPP performance (Liu, Love, Smith, Regan \& Davis, 2015), in the subsequent sections after the methodology section, the study examines key elements of a PPP governance system in order to propose strategies that would trigger PPP excellence and sustainability.

\section{Methodology}

Given that recent researchers have become interested in the analysis of documents (Bogdan \& Biklen, 1998), this study employs a review of literature to examine reported PPP governance practices. Although PPP governance 
seems understudied, literature review approach becomes relevant because a lot of research has been conducted distinctively on PPPs and governance. Accordingly, the study gathered information from journal articles, conference proceedings, studies and reports from research based organisations, and books that discuss the phenomena of PPP, governance and good governance. Because data had to be collected from various sources, theoretical sampling was utilized. Theoretical sampling is a process of data collection where the researcher simultaneously collects and analyses data to decide what data to collect next and from where (De Vos, 1998).

In order to address the study objectives, a two level data collection and analysis style was used. For the first level, three key words of PPP management, governance and good governance were used to search for relevant online documents, and thereafter each selected document was systematically read and content analysed right from the first page to the last one to identify a list of key PPP governance elements common in the documents. Subsequently, the developed list of key PPP governance elements was used at level 2 to search for relevant documents, and thereafter a computer based "control and find" option was executed in order to conduct a comprehensive data collection and content analysis only on relevant parts of the documents. However, where a document was primarily addressing one or more of the key PPP governance elements, had to be read and analysed in its entirety. In summary, collected and analysed data was condensed and described to create and present new knowledge and insights, facts and practical guidance on the advancement of PPP governance.

\section{Examining Key Elements of a Public Private Partnership Good Governance System}

Based on documentary reviews, PPP principles, critical success factors, risk management, stakeholder management and PPP maturity trajectory were identified as key elements of a PPP good governance system; and each of these is examined below.

\subsection{Principles of Public Private Partnership Good Governance}

Principles of good governance are standards of behavior that would enable delivery of public services to the expectations of citizens (Gisselquist, 2012). Therefore, 'good governance responds to collective problems of citizens and fulfils their needs in an appropriate and accepted way' (Yousaf, Ihsan \& Ellahi, 2016, p.201). Provided below is a critique of nine PPP principles.

\subsubsection{Value for Money}

Service provision without direct or indirect substantial value addition to processes and systems or ameliorating the lives of the beneficiaries is a complete waste of resources, efforts and time. Value for money (VFM) refers to the 'optimum combination of whole-of-life costs and quality (or fitness for purpose) of the good or service to meet the user's requirements (Mwangi, 2016, p.171). Best value out of the money collected and spent is an ideal objective for the public sector. This necessitates conducting a VFM test on both financial and non-financial benefits and costs over the whole life cycle of the project (Rothballer \& Kim, 2013). Public Sector Comparator (PSC) is the VFM analysis approach commonly used by public agencies to determine whether to take the PPP or public procurement route. However, PSC has had some criticisms and notable among them is 'optimism bias' depicted in the 'excessive use of low discount rate' (Sarmento \& Renneboog, 2016, p.101). In fact, the use of unreliable tools to measure value for money is one of the main PPP governance challenges.

According to Sundaram, Chowdhury, Sharma and Platz (2016) the potential of PPPs delivering services that have a bearing on social and economic transformation, over and above what public procurement would do is dependent on a country's institutional capacity to create, manage, monitor and evaluate PPP operations. Globally though, PPPs have had a poor governance record ranging from, but not limited to: the off-the-government budget target, overestimation of benefits and demand, underestimation of costs, weak incentives to support PPP activities, and the tendency of only investing in profit making projects (Sundaram et al., 2016).

\subsubsection{Dispute Resolution}

Although disputes are commonly associated with negativity, in some instances they have proved to promote open and meaningful discussions in identifying and addressing needs, concerns, interests and values of the various PPP participants for service delivery improvement (United Nations Economic Commission for Europe-UNECE, 2004). Such interpretation relates to integrative rather than distributive conflict management styles. Actually, using integrative approaches to resolve conflicts offers better results (Gad, 2012). Ironically, any positive outcome attained from distributive approaches benefits a few parties, and in the event that it becomes clear to the majority that they are disadvantaged in the partnership, more problems would arise than were thought to have been solved. Therefore, distributiveness causes less positive impact compared to integrative means. Table 1 provides appropriate mechanisms for resolving disputes among parties, and conditions under which each of them may apply. 
Table 1. A Comparison of different dispute resolution mechanisms

\begin{tabular}{|c|c|c|c|c|c|c|}
\hline $\begin{array}{l}\text { DRMs } \\
\text { Pt. of } \\
\text { comparison }\end{array}$ & Litigation & Arbitration & Mediation & Adjudication & DAB & $\begin{array}{c}\text { Expert } \\
\text { Determination }\end{array}$ \\
\hline $\begin{array}{l}\text { Parties } \\
\text { involved in the } \\
\text { decision }\end{array}$ & $\begin{array}{l}\text { Judges and } \\
\text { courts }\end{array}$ & Arbitrators & $\begin{array}{l}\text { Mediators and } \\
\text { Parties }\end{array}$ & Adjudicator & Panel of experts & An expert \\
\hline $\begin{array}{l}\text { Control level of } \\
\text { the parties }\end{array}$ & None & Minor & Full & Average & Average & Minor \\
\hline $\begin{array}{l}\text { Decision } \\
\text { enforceability }\end{array}$ & $\begin{array}{l}\text { Final and } \\
\text { binding }\end{array}$ & $\begin{array}{l}\text { Final and } \\
\text { binding }\end{array}$ & Non-binding & $\begin{array}{l}\text { Binding, if stated } \\
\text { in contract }\end{array}$ & Non-binding & Final and binding \\
\hline Privacy & Public & Confidential & Confidential & Confidential & Confidential & Confidential \\
\hline $\begin{array}{l}\text { Relative } \\
\text { duration }\end{array}$ & Very long & Long & Short & Short-set & Short & Short \\
\hline Relative cost & $\begin{array}{c}\text { Very } \\
\text { expensive }\end{array}$ & Expensive & Less expensive & Average & Average & Not expensive \\
\hline Key points & $\begin{array}{c}\text { Technical } \\
\text { knowledge } \\
\text { compromised }\end{array}$ & $\begin{array}{c}\text { Technical } \\
\text { knowledge not } \\
\text { compromised }\end{array}$ & $\begin{array}{l}\text { Solution may not } \\
\text { follow contract }\end{array}$ & $\begin{array}{c}\text { Decision can be } \\
\text { appealed }\end{array}$ & $\begin{array}{c}\text { DAB } \\
\text { knowledgeable of } \\
\text { project }\end{array}$ & $\begin{array}{c}\text { Preferred in } \\
\text { complex technical } \\
\text { issues }\end{array}$ \\
\hline
\end{tabular}

Source: Gad (2012, p.14)

KEY: DRMS $=$ Dispute resolution mechanisms. $\mathrm{DAB}=$ Dispute Adjudication Board. $\mathrm{Pt}=$ Part

The first column from the left side of Table 1 provides generic determinants of dispute resolution, and the first row at the top of the table provides a range of dispute resolution methods. Moving down in the columns of dispute resolution methods are features for each method as a benchmark of each generic determinant. The last row of the table provides the crucial issues about the application of each method in resolution of conflicts. In summary, distributiveness reduces as parties move away from litigation towards expert determination methods, and the reverse is true.

\subsubsection{Innovation}

Although literature tends to assume that innovation is a term of the private sector (Moore \& Hartley, 2010), it is equally no stranger to the public sector. By description, innovation is associated with a significant development of new or reinvention of ideas and processes, structures and resources, skills and activities, products and services, and practices novel to a unit of adoption (Ysa, Esteve \& Longo, 2013; Pestoff \& Brandsen, 2010). The paradigm shifts in the way public services have been provided over time such as centralised vs. decentralised systems, paper based vs. electronic-government, direct public sector provisioning, outsourcing, privatisation and the current PPP arrangements, are a reflection of innovative practices.

Normally, public sector innovations manifest in five different forms: provision of new services or goods to new beneficiaries; provision of an existing service to a new group of users; improving an existing service to satisfy the needs of old and new users; creation of new managerial practices or organisational features that are yet to be adopted or have recently been implemented; and collaborative transformation of complex social production systems through a network of organisations rather than focusing on changes solely within a single organisation (Ysa et al., 2013).

\subsubsection{Participation}

In a democratic society, citizens are obliged to directly or indirectly participate not only in shaping politics, but also exercising great influence in the delivery of public services for the development of their nations (Yousaf et al., 2016; Gisselquist, 2012). Any failure by public agencies or private partners to involve citizens in public service decision-making processes discredits the legitimacy of the government, hence leading to diminishing public support for future government interventions (Glaser, 2007).

\subsubsection{Sustainable Public Management}

Sustainable public management relates to the creation of public service conditions and systems that are adaptive 
to current and future changes in the institutional, social, economic, ecological, technological, political and legal environments in order to secure lives, create and safeguard properties and other public resources, and support the implementation of national development programmes for citizens' welfare (Dechev, 2015). Governments must have accurate data about; the past and current trends to predict future strengths and opportunities, weaknesses and threats in order to reform public institutions, policies, and administrative procedures that are transparent and sound to enlist public support in the development of society (Gisselquist, 2012). Concisely, governments need to be sure about, the current and the desired future public service delivery status, the necessary strategies for achieving the future status, and should ensure provision of the best public services on a sustainable basis (Graham et al., 2003). Therefore, shortage of such information and response has disastrous effects on the delivery of public services in the future. For instance, the setting in of the 2008 global financial crisis saw several PPP investment projects either cancelled or suspended or renegotiated due to price increases that had not been promptly predicted ahead of time.

\subsubsection{Transparency}

Transparency relates to the public's ability to freely access information and the willingness of government to provide reliable, comprehensive, understandable, timely, and internationally comparable information about the operations of public agencies, and having well-functioning systems that propel public and private partners behave ethically for the common good (Gisselquist, 2012). Legally, transparency is achieved when the citizens respect society rules, and an independent and incorruptible judiciary is in existence to assure the provision of public services in a fair and impartial manner (Van Doeveren, 2011). According to Greve and Hodge (2013, p.215), governments can never provide accurate information nor be transparent, as long as they continue to spend beyond what their nations can afford in order to sustain popular political support. Globally, PPP processes seem to be too weak to foster transparency. The World Bank Group (2016) reveals that, 23\% of the world's PPP projects are tendered through unsolicited proposals, while $39 \%$ of PPP contracts in low-income countries are awarded on noncompetitive terms.

Although information disclosure is essential for evaluating and determining government performance, the common trend with PPP projects is the exclusion of the public from decision-making processes. Kalpana (2014b), for example, claims that PPP negotiations are secretly handled and decision outcomes therefrom are never disclosed to the public, all in the name of commercial confidentiality. For instance, in 2000 the UK government refused to disclose to its parliament the full details that surrounded the termination of contracts for 10 companies that had been providing support services to the National Health Service (Hood, Fraser \& McGarvey, 2006, p.44). Similarly, in 2001 the Australian parliament was denied access to a contract deed between the national roads authority and the private company for the M2 motorway project in New South Wales (Reeves, 2013). Hood et al. (2006) further noted that 'neither the public nor the private sectors display adequate transparency in either their risk allocation or the apparent rewards flowing from the contracts'.

\subsubsection{Accountability}

Accountability is the acceptance by an individual or institution to take up public service delivery responsibilities and thereafter be answerable to the citizens for one's actions (Forrer, Kee, Newcomer \& Boyer, 2010). Such compels PPP actors to seek clear objectives, develop effective strategies, focus on results, and monitor and report on performance (Cheema, 2007). Essentially, accountability is a means of detecting errors, taking corrective action, eliminating corruption and promoting transparency with a primary target of bettering performance rather than punishing suboptimal performance (Peters, 2007).

Kalpana (2014b, p.69) claims that PPPs have eroded public accountability because "who is accountable for what and to whom' questions remain unanswered. Whereas the provision of public accountability is a cardinal role of government, service delivery participating individuals remain solely responsible for their actions. In fact, any actions that relate to exercising public powers or using public resources or providing public services demand for one's accountability (Reeves, 2013).

\subsubsection{Networking}

PPP arrangements take place in a network consisting of the market, civil society, public organisations, community and individual citizens that are brought together through collaborative efforts of interdependent and interactive resources and processes, to deliver more and better public services than what one or a few actors would accomplish on their own (Xu, Sun \& Si, 2015). Because the public as well as other sectors have limited or lack certain resources, implies that none of them can fully achieve its objectives without utilising resources possessed by actors in other sectors (Klijn \& Teisman, 2003). Successful networking would therefore necessitate different actors uniting to share values, information and other resources towards generating innovative and collective solutions (Klijn, 2010). 
However, the multiplicity of PPP actors with diverse and often conflicting traditions, perceptions and interests complicates the functioning of network-based processes. This view is shared with Klijn (2010, p.307) who argues that 'all actors demand a say in the decision-making process, and their inclusion makes decision making within governance network immensely complex'. Improper PPP governance partly results from: lack of information and knowledge about causes and effects of ineffective networking; failure to identify the actual motives why each of the actors joins the network; ineffective or lack of inter-network communication; and deliberate efforts by some actors following their own organisation's rules and norms while sacrificing those of the network (Alexander, 2013).

\subsubsection{Trust}

Trust is one's belief that the partner will behave and act according to his or her promises with consistency (Muhwezi, 2010). Traits that operationalise trust include credibility, benevolence, integrity, contractualism, competence, and goodwill (Verhoest et al., 2013; Sako, 1992). As such, PPP trust based traits are induced by formal and informal instruments conveyed through contracts, relational interactions, speculations, faith, and reliance. As well as confidence among the actors and their willingness to refrain from opportunistic behaviour, even when avenues for acting opportunistically show up. However, PPP engagements often times depend on contractual and institutional rules in order to avoid risks and uncertainties that come with informal and relational mechanisms. Such is prompted by among others, the absence of confidence among parties based on past-experience, and having inter-organisational actors with dissimilar characteristics and interests (Verhoest et al., 2013).

Whereas trust reduces transaction costs, facilitates cooperation and stability in network relations, and stimulates learning, knowledge exchange and innovation, but the acceptance of one to trust another partner lends himself/herself to opportunistic behaviour (Klijn, 2010) unless rational decisions have been made through calculative risk taking. In summary, PPP trust facilitates fluent interactions and information flow, enables actors to develop innovative solutions within complex networks; and becomes stronger as interactions and reciprocity among actors improve, but unnecessary without risk (Klijn, 2010).

\subsection{Public Private Partnership Critical Success Factors}

Critical success factors (CSFs) are core aspects of an activity where things must be done correctly or in which favourable results are absolutely necessary for the achievement of organisational or project goals (Chan, Lam, Chan, ASCE, Cheung \& Ke, 2010; Liu et al., 2015). Figure 1 provides a comprehensive list of critical success factors for PPP projects.

\section{Critical Success Factors for PPP Projects}

special bid features, entrepreneurship and leadership, appropriate project identification, acceptable toll/tariff levels, selection of suitable subcontractors, knowledge and technology transfer, environmental impact, approval processes, existing strategic alliance, resource management, trust, feasibility studies, financial capability, complementary skills, effective planning, appropriate concessionaire selection, resource dependency, common goal symmetry, intensive communication, effective negotiation, robust business case, well drafted output specifications, efficient consultation with end-users, balanced performance measurement system, commitment and adequate resourcing of projects, appropriate composition of the project team, transparent and competitive procurement process, good governance, well-organized and committed public agency, shared authority between the public and private sector, appropriate risk allocation and sharing, good private consortium, favourable legal framework, provision of guarantees by government, multi-benefit objectives, stable macro-economic conditions, sound policies, favourable investment environment, economic viability of projects, sound financial package, business diversification, credit rating of investors, teamwork, existing infrastructure, delivery of asset, sound institutional frameworks, private sector financial objectives, value-for-money objectives and analysis, standardization of procedures, unifying specific vision, willingness to compromise/collaborate, respect, community outreach, expert advice and review, risk awareness, clear roles and responsibilities, shared responsibility, stable political and social support, judicious government control, asset quality, internal coordination within government, corporate governance, governmental supervision, clarification of contract documents, technical support and innovation, supportive project team and management actions

Figure 1. Critical success factors for public private partnerships

Adapted from Liu et al. (2015) 
Notwithstanding the provision of a comprehensive list of CSFs, after a review of five studies on PPP CSFs (see Alinaitwe \& Ayesiga, 2013; Chan et al., 2010; Aerts, Grage, Dooms \& Haezendonck, 2014; Li, Akintoye, Edwards \& Hardcastle, 2005; Osei-Kyei \& Chan, 2015) results indicated that each PPP CSF may have different impact levels on different sectors, actors, countries and across projects, and research results may differ depending on the methodologies and the category of respondents used.

\subsection{Stakeholder Management}

A stakeholder is any institution or individual that has an interest and/or the power to influence project transactions and outcomes. As such, a shareholder affects the success of a project or is affected by the implementation of a project. For instance, according to Martin, Lawther, Hodge and Greve (2013) PPP projects are unsuccessfully implemented because of lack of a sense of project ownership and commitment from the public. On the other hand, effective stakeholder engagement promotes a shared vision, minimises project opposition, improves investment needs assessment, strengthens citizens' trust in government actions, and enhances partners' credibility and commitment from politicians and citizens for public projects (OECD, 2015; Felsinger, 2011). In fact, full support from project stakeholders is a recipe for effective provision of public facilities and services through faster and quality project deliveries, and minimised project conflicts and cancellations.

However, PPP stakeholder involvement has been associated with many intricacies. These include a multiplicity of stakeholders with divergent roles, interests and concerns that are difficult to reconcile; and monopolistic control over PPP information flow by a few stakeholders (See Felsinger, 2011; Kalpana, 2014a). For instance, governments selectively disclose PPP project information in order to avoid future public uprising in case certain project targets are never realized. Meanwhile De Schepper, Dooms and Haezendonck (2014) relate stakeholder management problems to a mismatch in the application of reactive and proactive approaches, lack of guidance on stakeholder responsibilities, PPP accountability complexities, and the perception that stakeholder inclusion is "an activity that consumes substantial amount of resources and time".

Instead of take advantage of the diversity of experiences, skills, knowledge, and information as a valuable means of improving PPP products and processes, it would be irrational for any stakeholder to think that by behaving in a non-transparent and discriminatory way, and deliberately avoiding accountability, better results would be produced. Hence, the different roles and interests of each stakeholder are meant to strengthen the partnership relationship (Kalpana, 2014a:17) than weaken it; and as Felsinger (2011) argues, participation of all stakeholders in PPP processes is a critical factor for project success. Unless all project stakeholders are known, and their roles and interests have been clearly identified and effectively managed, PPP projects are bound to receive a lot of resistance.

\subsection{Public Private Partnership Maturity Trajectory}

The pace at which PPP systems develop is contingent on a country's social and economic development needs, and the capacity and willingness of both the public and private sector institutions to devote sufficient resources towards creating robust PPP environments $(\mathrm{Nel}, 2014)$. Determinats of PPP maturity include investment climate, financial facilities, legal, regulatory, institutional, operational, and subnational adjustment factors (Infrascope, 2015). Although both developed and developing countries are good at identifying development objectives, they, however, remain at different levels of PPP development. In fact, whereas developing countries fail to meet most of their infrastructure development needs because of resource capacity constraints and poor PPP governance, the developed world has had relatively successful PPP regimes in almost all sectors (See Eggers \& Startup, 2006).

For instance, the low PPP maturity in Africa emanates from a number of factors. These include; lack of robust local hedging instruments and financing markets, and overreliance on external financing; improper harmonisation of PPP practices among ministry level agencies, and between national and sub-national levels; political distortions; lack of effective stakeholder engagement over tariffs, tolls and fees; slow progress in the passing of PPP laws and low speed in project development; failure to factor fiscal risks and public debt into fiscal frameworks; and poorly implemented PPP laws (Infrascope report, 2015). Nevertheless, less developed PPP markets are better placed to move more rapidly and leapfrog to more advanced stages of maturity than the present mature PPP markets were able to. Emerging PPP markets not only have the opportunity of learning from and using more innovative PPP approaches already developed by PPP mature markets (Eggers \& Startup, 2006), but they also easily attract assistance from multilateral organisations.

\subsection{Public Private Partnership Risk Management}

Risk is the possibility of adverse events occurring and subsequently causing deviations in actual project outcomes or threatening the successful completion of projects (Aldrete, Bujanda \& Valdez-Ceniceros, 2010; Manrique Millones, 2010). As such, PPP risks arise from the uncertainty about the future occurrence of some events and 
their impact on project activities (Yong, 2010:15), which erupt when vulnerable PPP conditions are exposed to a threat (Burger, Tyson, Karpowicz \& Coelho, 2009). Because PPP projects are conducted within a very diverse and evolving environment, they tend to be exposed to numerous risks (see Table 2).

Table 2. Classification of common public private partnership risks

\begin{tabular}{ll}
\hline Risk classification & Examples of risks \\
\hline Political & $\begin{array}{l}\text { Nationalization of assets, termination of concession without appropriate } \\
\text { compensation, political/public opposition, corruption, poor decision making } \\
\text { processes }\end{array}$ \\
\hline Commercial & $\begin{array}{l}\text { Inflation, fluctuations in interest and currency exchange rates, tariff changes, poor } \\
\text { financial markets and hedging instruments, restrictions on currency convertibility } \\
\text { and transfer of profits, price changes, changes in monetary policies, construction } \\
\text { of competing alternative facilities (e.g. toll free roads), inability of government to } \\
\text { pay creditors and other services providers, refinancing problems }\end{array}$ \\
\hline Legal & change in laws and new policy enforcement, change in contract obligations, \\
& inappropriate legal and institutional frameworks, Poor contracts supervision \\
\hline Relationship & Lack of commitment from government or private party, poor organisation and \\
coordination & Improper designs and specifications, high costs and longer planning time, changes \\
in technical standards, poor solution to public need, inadequate competition for \\
procurement
\end{tabular}

Force majeure Unforeseen weather conditions, geotechnical conditions, wars, natural disasters

Developed from Manrique Millones (2010); Thieriot and Dominguez (2015); Abednego and Ogunlana (2006); Rothballer and Kim (2013)

The identification of risks by classifications in Table 2 intimates that PPP risks arise from different environments. For instance, the political, commercial and legal risks are largely triggered by public sector structures and general conditions of a country. The force majeure risks are mainly caused by natural and to a lesser extent by man-made conditions, and tend to be outside the direct control of any of the PPP parties. As for relationship, planning and procurement, construction, and operating and maintenance risks relate to changing conditions within the project lifecycle mainstream activities, and these would be easy to control when all PPP participating parties cooperate and are committed to project transactions. Therefore, PPP projects risks can be comprehensively known and 
effectively managed when they are identified by the source of their cause. Whereas some of the risks such as cost overruns, delays, and poor quality and documentation overlap across risk classifications, the frequency and magnitude of their impact differs within different PPP operating environments.

\subsubsection{Assessment of Key Mechanisms of Public Private Partnership Risk Management}

Given that the entire study in one way or the other tackle risk management issues, this subsection therefore only limits the assessment of risk to PPP forms, government guarantees, and renegotiations.

\subsubsection{Public Private Partnership Forms}

In addition to other contractual arrangements, in a typical PPP environment, various forms of PPPs are used to distribute project responsibilities between the public and private sector parties as a means of containing the occurrence of risks and their negative impact on service delivery outcomes. Table 3 provides a narrative summary of the responsibilities assumed by the private and public sector actors in each PPP form.

Table 3. Description of public private partnership forms

\begin{tabular}{|c|c|c|}
\hline PPP Form & New or Existing & Description \\
\hline Design-Build (DB) & New & $\begin{array}{l}\text { The public sector contracts a private sector organisation to } \\
\text { undertake most of the design work and all the construction } \\
\text { tasks of the projects at a fixed fee. The provision of funding } \\
\text { throughout the project, and the operating and maintaining } \\
\text { of the facility after its construction is the sole responsibility } \\
\text { of the public sector. }\end{array}$ \\
\hline $\begin{array}{l}\text { Design-Build-Maintain } \\
(\mathrm{DBM})\end{array}$ & New & $\begin{array}{l}\text { The public sector contracts the private organisation to carry } \\
\text { out the design and construction works, and thereafter } \\
\text { maintain the facility during its usage. The public sector } \\
\text { remains responsible for all the funding needs and operation } \\
\text { of the facility. }\end{array}$ \\
\hline $\begin{array}{l}\text { Design-Build-Finance } \\
\text { (DBF) }\end{array}$ & New & $\begin{array}{l}\text { The public sector contracts the private sector organisation } \\
\text { to design, construct and provide partial or full funding for } \\
\text { the construction phase. The public sector retains } \\
\text { responsibility over long-term operation and maintenance of } \\
\text { the project. }\end{array}$ \\
\hline $\begin{array}{l}\text { Design-Build-Operate } \\
\text { (DBO) }\end{array}$ & New & $\begin{array}{l}\text { The private sector designs and constructs the public facility, } \\
\text { and is handed over to the public entity upon completion. } \\
\text { Thereafter, the public sector grants permission to the same } \\
\text { private company to operate the facility for a defined period. } \\
\text { In addition to having full ownership rights, the public } \\
\text { sector is also responsible for funding the designing, } \\
\text { building, as well as paying the private sector company for } \\
\text { operating the facility. }\end{array}$ \\
\hline $\begin{array}{l}\text { Lease-Operate-Maintain } \\
\text { (LOM) }\end{array}$ & Existing & $\begin{array}{l}\text { The public sector leases a public facility to a private } \\
\text { organisation for a definite period. The private partner } \\
\text { becomes responsible for maintaining and operating the } \\
\text { facility as per the leasehold agreement. However, the } \\
\text { ownership and investment decisions of the infrastructure } \\
\text { remains entirely a responsibility of the public sector. }\end{array}$ \\
\hline
\end{tabular}




\begin{tabular}{|c|c|c|}
\hline $\begin{array}{l}\text { Design-Build-Operate- } \\
\text { Maintain (DBOM) }\end{array}$ & New & $\begin{array}{l}\text { The private sector assumes the responsibilities of designing } \\
\text { and constructing the public facility, as well as operating and } \\
\text { maintaining the same facility for a specific period. The } \\
\text { public sector remains responsible for all financing needs of } \\
\text { the project. }\end{array}$ \\
\hline $\begin{array}{l}\text { Design-Build-Finance- } \\
\text { Operate (DBFO) }\end{array}$ & New & $\begin{array}{l}\text { The public sector contracts the private company to design, } \\
\text { build, operate, and finance all the project activities for a } \\
\text { defined period, except the maintenance of the project and } \\
\text { its associated funding needs remain responsibilities of the } \\
\text { public sector. }\end{array}$ \\
\hline $\begin{array}{l}\text { Design-Build-Finance- } \\
\text { Operate-Maintain } \\
\text { (DBFOM) }\end{array}$ & New & $\begin{array}{l}\text { The public sector contracts a private company to design, } \\
\text { build, operate, maintain as well as financing all the projects } \\
\text { activities for a defined period. The private sector receives } \\
\text { payment for its services from the government. }\end{array}$ \\
\hline Concession & Existing & $\begin{array}{l}\text { The government grants private company exclusive rights to } \\
\text { operate and maintain an existing public facility to provide } \\
\text { services to the citizens in accordance with government } \\
\text { performance standards. During the concession execution } \\
\text { period, the public sector retains ownership over the original } \\
\text { asset, while the private company owns any improvements } \\
\text { made to the facility. However, at the end of the concession } \\
\text { period, the public sector fully owns the facility including } \\
\text { all the upgrades. }\end{array}$ \\
\hline $\begin{array}{l}\text { Build-Own-Operate- } \\
\text { Transfer (BOOT) }\end{array}$ & New & $\begin{array}{l}\text { The government grants a franchise to a private partner to } \\
\text { finance, design, build and operate a facility for a specific } \\
\text { time. Ownership of the facility is transferred back to the } \\
\text { public sector at the end of contract period. The private firm } \\
\text { receives payment from the service or facility users. }\end{array}$ \\
\hline Build Own Operate (BOO) & New & $\begin{array}{l}\text { The private sector finances, builds, owns and operates the } \\
\text { public facility in perpetuity. The private sector is not only } \\
\text { entitled to all the rewards but is also responsible for } \\
\text { managing all the project risks. }\end{array}$ \\
\hline
\end{tabular}

Developed from Eggers and Startup (2006); U.S. Department of Transport (2016); Sanda, Daniel, Akande and Adeagbo (2016); Lammam, MacIntyre and Berechman (2013)

The private sector has two options of participating in PPPs. Either by using the existing public facilities to provide public service, where it may be mandated to improve the facility too, or to build a new public facility that will be used for the first time when construction is complete. According to Poole, Toohey and Harris (2014) PPP forms are the main determinants of PPP project risks allocation and sharing. When the public or private sector organisations take up less or more responsibilities, so are the number of risks they are set to manage (See Figure 2 below). 


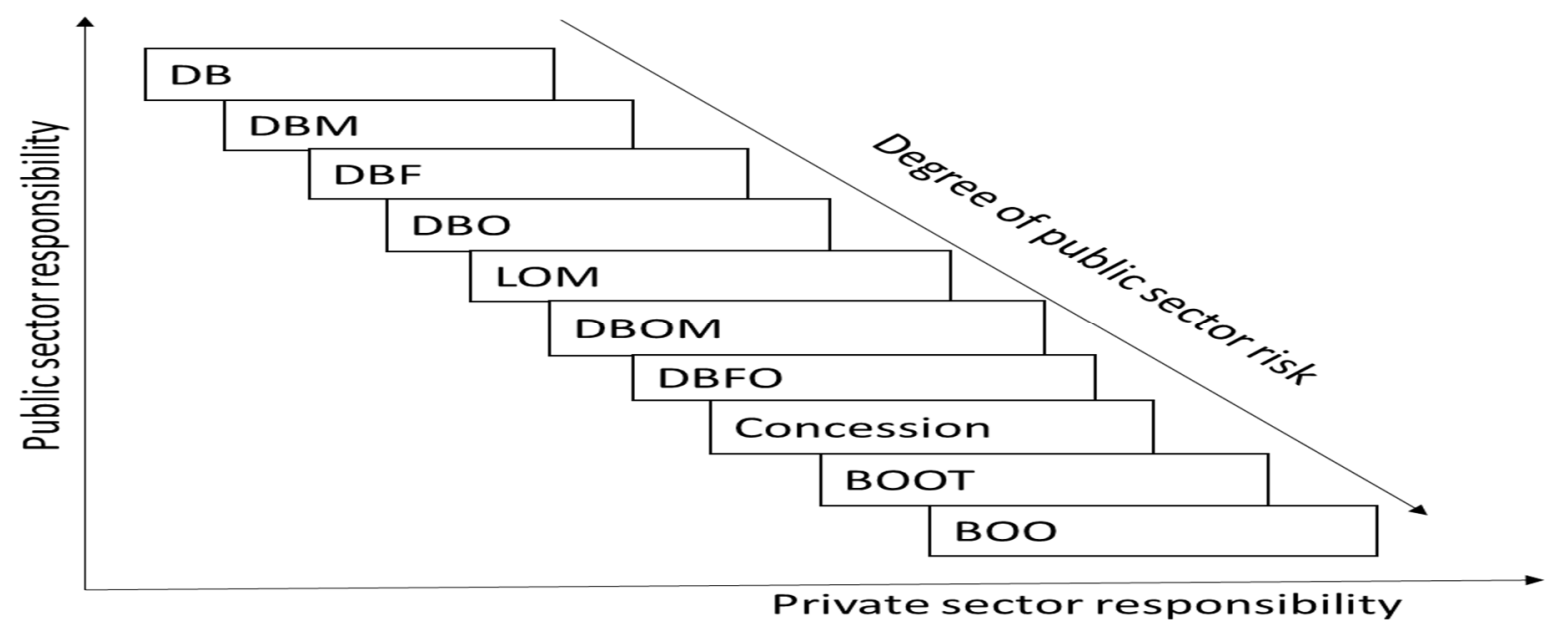

Figure 2. Partners' risk assumption based on public private partnership forms

Source: Author

Sloping the grid from the $\mathrm{DB}$ to $\mathrm{BOO}$, the private sector responsibilities and risks keep increasing, whereas the public sector's responsibilities and risks are greater as it moves up the grid from BOO to DB, and the reverse is true for both parties.

\subsubsection{Public Private Partnership Renegotiation}

Based on Guasch, Benitez, Portabales, and Flor (2014:4)'s descriptions, we define renegotiations as negotiation processes which are focused on making changes to the original PPP contract due to significant changes in the current risk matrix assignment and contract conditions, as well as changes in the project scope that were never provided for in the contract. Whereas requesting changes to a PPP contract is an entitlement to all parties, in practice the private sector makes renegotiation requests more often than public entities.

Although there is limited scholarly writing on renegotiation, PPP projects are a common setting for contract renegotiations. The frequency of renegotiation occurrences, the ever-increasing investment costs associated with them, and their occurrence shortly after contract signing, not only manifest imprudent risk allocation, poor contract design and implementation, but also an abuse of the good intentions for preventing failure or cancellation of contracts upon which renegotiation processes were conceived (Yong, 2010). For instance during the construction of a concert hall in Budapest city in Hungary, the project's investment costs increased from 175 to 827 Million Euros after renegotiation because the original contract lacked some technical features of the building (Dechev, 2015). And on average, PPP contracts are renegotiated a year after contract signing, and they occur in about 68 out of 100 PPP projects (Guasch et al., 2014).

Yong (2010) argues that PPP renegotiations occurring worldwide are generally based on "opportunistic behaviour of actors to secure extra benefits rather than a lack of completeness in contracts". Consequently, renegotiations are becoming a critical problem to the implementation of PPP projects. There are many drivers of renegotiations with negative consequences on PPP project success (see Figure 3). 


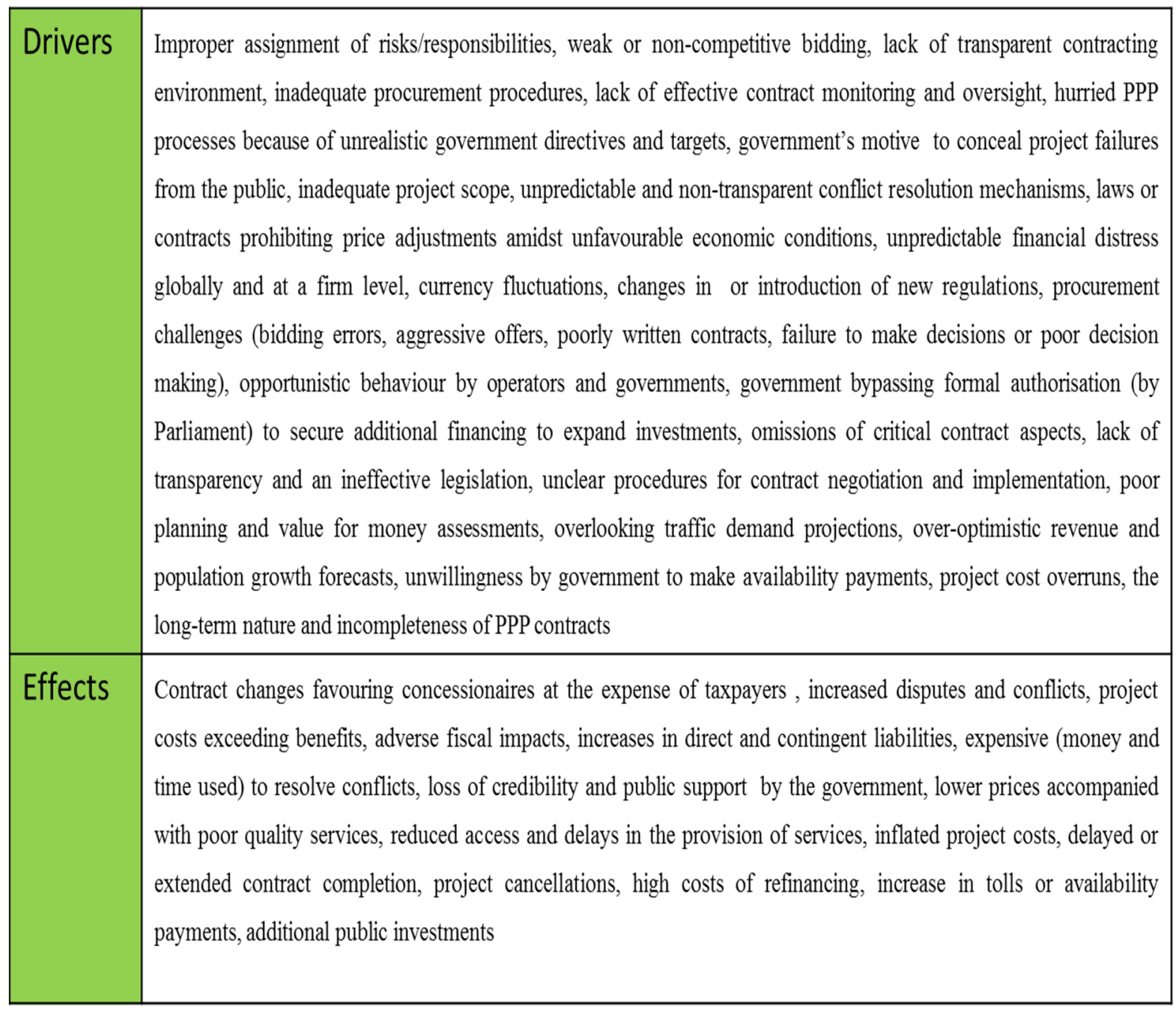

Figure 3. Common causes and effects of PPP contract renegotiations

Developed from Marques and Berg (2011); Guasch et al. (2014); Dechev (2015); Perkins (2013); Poole et al. (2014)

\subsubsection{Public Private Partnership Guarantees}

PPP guarantees are protective instruments used to assure continuation of contract implementation or service provision amidst tough conditions. They are only performed upon the occurrence of risks covered under them. While the private sector provides guarantees such as bid and performance bonds, this study only focuses on government guarantees.

Given that majority of the PPP risks are often beyond the direct control of the private sector, PPPs tend to be less attractive to private investors. Such is aggravated by heavy private sector investment in PPP projects, yet revenue comes in after a long time and payment is spread over many years. Consequently, the government uses guarantees to make PPP projects commercially viable, and to safeguard private sector interests (Aldrete et al., 2010; Irwin, 2007). However, failure by the public sector to cautiously allocate and share risks with the private sector, may cause the government to find guarantees very costly to implement. Examples of PPP guarantees are described in Figure 4. 


\begin{tabular}{|c|c|}
\hline Guarantees & Description \\
\hline Equity & $\begin{array}{l}\text { The concessionaire is granted an option to be bought out by the government with a guaranteed minimum } \\
\text { return on equity. The private sector performance incentives are drastically reduced, as government } \\
\text { essentially assumes all project risks }\end{array}$ \\
\hline Debt & $\begin{array}{l}\text { The government provides assurance and commitment to repay the lender (credit provider of the project } \\
\text { company) the amount due and guaranteed subject to terms and conditions of the agreement, in case the } \\
\text { borrower defaults. The government's exposure to risk increases as the private sector's incentives reduce }\end{array}$ \\
\hline Exchange rate & $\begin{array}{l}\text { The government compensates the concessionaire for increases in the local cost of debt service or any other } \\
\text { payments due to exchange rate movements. The compensations are made where the exchange rate } \\
\text { fluctuations exceed a defined limit }\end{array}$ \\
\hline $\begin{array}{l}\text { Grants and } \\
\text { subordinated } \\
\text { loans }\end{array}$ & $\begin{array}{l}\text { Governments can furnish grants or subordinated loans as a cash or in-kind contributions. Whereas } \\
\text { subordinated bonds are repayable after the project is successful or repaid before returns to equity are made } \\
\text { but after senior loans have been paid, grants on the other hand are non-repayable contributions. }\end{array}$ \\
\hline Shadow tolls & $\begin{array}{l}\text { The government contributes a specific periodic payment per vehicle recorded on the facility/road. The } \\
\text { government contribution increases or reduces with an increase or reduction in traffic (facility usage) } \\
\text { respectively }\end{array}$ \\
\hline $\begin{array}{l}\text { Minimum traffic } \\
\text { or revenue }\end{array}$ & $\begin{array}{l}\text { The government compensates the concessionaire in cash if traffic or revenue falls below a specified } \\
\text { minimum level. The minimum traffic or revenue threshold should be set below the expected level in order to } \\
\text { reduce government risk exposure. With these guarantees, governments normally limit the maximum amount } \\
\text { of revenue the project developer can retain }\end{array}$ \\
\hline $\begin{array}{l}\text { Concession } \\
\text { extensions }\end{array}$ & $\begin{array}{l}\text { The government can extend the concession term if revenue falls below a minimum amount. The extension } \\
\text { terms do not impose any cash neither cost on the government nor provide any short-term protection to } \\
\text { investors from traffic and revenue shortfalls }\end{array}$ \\
\hline $\begin{array}{l}\text { Revenue } \\
\text { enhancements }\end{array}$ & $\begin{array}{l}\text { The government may enhance revenues by limiting competition, building complementary facilities to feed } \\
\text { traffic to the concession, and allowing for the development of ancillary facilities above or adjacent to the } \\
\text { facility. However, such agreements restrict public control over future development, which may be } \\
\text { unattractive to the public partner }\end{array}$ \\
\hline
\end{tabular}

Figure 4. Common types of government guarantees

Developed from Fisher and Babbar (1996)

Descriptions in Figure 4 indicate that each of the guarantees is suitable in specific conditions, and their impact on the government's risk exposure and the private sector's incentives to execute its duties, vary across guarantees. Fisher and Babbar (1996) further noted that a combination of guarantees can be used in a single project, as long as they complement one another or the conditions for their use ensue.

The most preferred guarantees are grants, subordinated loans, minimum traffic or revenue guarantees and shadow tolls, because they significantly incentivise the concessionaire to perform the contract with less difficulties, and at the same time cause minimal risk impacts to the government. On the other hand, although revenue enhancements, concession extension, equity, debt, exchange rate guarantees easily attract private sector participation, they, however, pose long-term sustainability challenges. For instance, because of the high risks associated with equity, debt and foreign exchange guarantees, the government may fail to fulfil its commitments in the future, especially where many projects are being undertaken and such guarantee claims have to be effected on almost every project. As for revenue enhancements, the public sector may fail to undertake critical future investments in some geographical areas and/or make wrong investment decisions by trying to protect private sector interests. Meanwhile, concession extensions delay project completion with their envisioned service impacts, and they are, as such, not the best option when the concessionaire has financial challenges that may require quick financial solutions.

Other government guarantees include political risks guarantees (e.g. for deprivation of project assets, political violence, and breach of contract) (Tsukada, 2009); and tax exemptions and land incentives (Economic and Social Commission for Asia and the Pacific, 2011). 


\subsubsection{A Discussion on Risk Allocation and Management}

The decision for the private sector to participate in the provision of public services is conditioned on the effective allocation of PPP project risks (Marques \& Berg, 2011). The ability of the private sector to satisfy public service needs, while realizing profits, are key issues to consider when making risk transfers. Otherwise, PPP projects may not attract enough competition to enable the contracting of world-class companies. On the other hand, the public sector should not assume risks that it cannot effectively control nor should it transfer to other parties risks to which it is in the best position to manage. As a principle, risk must be allocated to a party that is most able to manage it (Reim, 2009) at the lowest cost possible without compromising quality. For instance, the public sector can best handle most of the legal and political risks, and the private sector is more suitable for handling most of the project design, construction, and operation and maintenance risks (Lammam et al., 2013). Lammam et al. further suggest sharing of risks (e.g. force majeure risks) where none of the parties is in a better position to manage them.

Although most PPP literature tend to portray risk allocation and sharing to be between the public and private sector parties on one hand, and among the public sector actors on the other, this same practice is also real among private sector actors themselves. Under the special purpose vehicle arrangement, project sponsors redistribute risks allocated to them by the public sector through separate contract agreements with many other private parties. For instance, project liabilities and asset responsibilities, and capital contributions risks are shared by shareholders; design and construction risks are borne by Engineering procurement and construction contractors; project materials and equipment provision risks are allocated to supply contractors; operating and maintenance risks are assumed by operating and maintenance contractors; and project debt financing risks are allocated to lenders (Alfen, Kalidindi, Ogunlana, Wang, Abednego, Frank-Jungbecker, Jan, Ke, Liu, Singh \& Zhao, 2009).

Effective risk allocation in PPP contracts has proven to reduce operational financial costs and increase revenue collections, to provide incentives for sound management of projects, and to minimise the number of renegotiation applications (Marques \& Berg, 2011). However, PPP projects that have regarded risk allocation as inconsequential, have their operations characterised by: making of untimely and wrong decisions, miscommunication, mismanagement of project lifecycle processes, dissatisfaction of facility and service users, adversarial relationships between parties, and discriminative contract documents which protect public sector interests at the expense of interests of other actors (Abednego \& Ogunlana, 2006).

\section{Public Private Partnership Good Governance Strategies}

This section highlights strategies based on the key elements of a PPP good governance system examined in section 3.

\subsection{Strategies for Public Private Partnership Principles}

Strategies are being provided for every PPP principle examined in subsection 3.1.

\subsubsection{Value for Money}

Sound VFM is realisable when: PPP projects have been selected and implemented correctly; contracts are thorough enough to enable realistic pricing and risk allocation; comprehensive and transparent fiscal and reporting systems are in place; and legal, regulatory and monitoring mechanisms that support citizens' welfare and sustainable development have been established and complied with (Sundaram et al., 2016). As well, trading off multiple objectives that drive value for money becomes paramount. Such objectives include risk transfer, whole of life costing, output specifications, competition, performance measurement, bankability, affordability and management skills (Public Private Infrastructure Advisory Facility, 2015). These in turn lead to reduced public opposition and unrest, minimised optimistic behaviour and project risks, improved competitive bidding, responsible accounting, fair project selection and implementation, and provision of adequate and quality services.

\subsubsection{Dispute Resolution}

The principal safeguard against dispute havoc is to include conflict resolution mechanisms in policy documents and contracts (UNECE, 2004). In fact, deviating from dispute management fundamentals results in delays, lowered team spirit, increased costs and damaged business relationships, which hamper project progress. Recent trends indicate that PPP contracts are adapting multi-tier systems of conflict resolution, where the aim is to start with the less expensive and less formal dispute resolution methods, and progressively move to the more expensive and more formal ones until the disputes have been resolved (Gad, 2012). For instance, unless alternative dispute resolution mechanisms have been applied without tangible success, most PPP participants would not litigate their differences because the court systems are procedurally too slow, expensive, and corrupt. However, this behaviour can change if the judiciary is seen to be very independent, neutral and the court systems have been left to be efficient without undue influence in settling cases. 


\subsubsection{Innovation}

A number of ways have the potential of improving public sector innovation for PPP projects. According to Moore and Hartley (2010) government must; create network-based production systems; tap into new pools of financing, material resources and human energy; redefine private rights and responsibilities; redistribute the right to define and judge the value of what is being produced; and justice, fairness and community building as well as efficiency and effectiveness must guide performance evaluations. Additionally, Ysa et al. (2013) suggest institutional and leadership factors. At the institutional level governments must; devote high initial financial resources to maintain relationships with private partners; work collaboratively with private partners to have entry into new markets and access unique resources and capabilities; improve communication and information exchange; increase market power in government business; and reduce liabilities of foreignness and government or trade barriers. While at the leadership level, public servants must exhibit proactive personality, networking and entrepreneurial spirit. Resultantly, an innovative public sector not only improves public service provision, but also facilitates the citizens' confidence that the government is credible enough to serve community interests sustainably.

\subsubsection{Participation}

The position of citizens in the delivery of public services must be strengthened through representative political democracy, participative democracy, consumerism, and co-production (Pestoff \& Brandsen, 2010). To have constructive public participation in public service delivery processes, government needs to guarantee freedom of association and expression (Van Doeveren, 2011), and allow open competition for entrants into the PPP market unless the prevailing circumstances would require use of other procurement methods that are less competitive; and to also respond timeously to citizens' concerns and with utmost care and due diligence.

\subsubsection{Sustainable Public Management}

Public institutions and processes must serve and create opportunities for the benefit of the citizens as a whole. Avoid giving any special treatment to the advantaged groups or marginalizing the disadvantaged groups (Glaser, 2007). Sustainable public service delivery must be pegged on a combination and trade-off between economy, efficiency and effectiveness (Mwangi, 2016). As such, the public sector must ensure that; the provision of public services is free from political or any other form of interference, the available resources are put to best use, quality standards are established, and government gets fully committed to ensuring that the existing policies are correctly implemented (Van Doeveren, 2011).

\subsubsection{Transparency}

Whereas confidentiality is one of the measures for transparent information disclosure, it should never be used as an excuse for refusal to disclose non-classified information nor involve citizens in PPP dealings, unless such actions are a true reflection of the existing and sound legal framework provisions.

\subsubsection{Accountability}

Complementary means must be employed to improve PPP accountability. Reeves (2013) recommends the use of transparent value for money analysis, competitive contracting through rigorous tendering processes, well drafted contract documents and effective contract management, and exercising oversight functions through auditing and scrutiny by parliament. Peters (2007) suggests a systematic accountability performance approach that requires defining outcomes and outputs, developing effective measurement mechanisms, linking programs to outputs and outcomes, defining standards, defining improvements and responsibilities, and linking inputs to outputs. While, Forrer et al. (2010) advocates for project lifecycle accountability safeguards through risk management, cost and benefits analysis, management of social and political impacts, specialised expertise, collaborative partnership, and balanced performance measurements.

\subsubsection{Networking}

PPP networks management must guarantee: interactions based on reciprocity, collaboration, trust and loyalty; resource exchanges based on complementary interests; equal status and fair treatment of actors; joint development of policies; conflict resolution based on members' reputation rather than sanctions; performance measurement based on goal achievement and participants' satisfaction with processes; and agreement on joint solutions to problems (Verhoest et al., 2013; O'Toole \& Meier, 2010). In summary, interdependent actors and interactive process complexities must be successfully navigated and managed, and network responsibilities executed with specialised skill to enhance social capital. Finally, the stronger the level of trust among the various members of a PPP network the likelihood of actors becoming more innovative towards solving complex policy problems for better performance (Klijn, 2010). 


\subsubsection{Trust}

Trust can be sustained among PPP partners by: forming joint expectations, whereby what needs to be achieved, who does what and in what capacity must be agreed upon; managing risk to avoid future vulnerabilities and opportunistic behaviour; managing power imbalances throughout the life of the project; managing knowledge transfer to enable inter-organisational learning for holistic performance; and managing network dynamics through effective communication, harnessing differences, and nurturing cultural awareness to avoid misaligned expectations and stereotyping problems (Vangen \& Huxham, 2010).

\subsection{Strategies for Critical Success Factors}

Because the impact level of a single or group of PPP CSFs may vary across environments, therefore, their application must be based on case-by-case scenario. However, regardless of the dynamics in the PPP environment or research pattern, CSFs of a strong private sector, transparent procurement, and appropriate risk allocation and sharing have been found to have the greatest contribution to the success of any PPP project. As such, some PPP CSFs are more important than others are, implying that the highest impacting CSFs should be accorded more attention and effort compared to the rest.

\subsection{Strategies for Stakeholder Management}

All stakeholders should be informed, involved, consulted and supported through effective and transparent communication throughout the project. Stakeholder iterative communication programs customized to the local and PPP context, such as opinion research, stakeholder consultation, public awareness and education are critical in building collective PPP support (Felsinger, 2011). As well as, establishing appropriate management processes in identifying and addressing stakeholder concerns, and reconciling their differences to realize everyone's full support. For instance, during project designing potential bidders' input should be sought, and after bidder engagement sessions all bidders should be sent full responses relating to concerns raised during the meetings (Felsinger, 2011). However, no stakeholder should misuse his/her roles with their attendant responsibilities to satisfy individual selfish interests. Stakeholder interests should be advanced and met using channels and processes that promote the common good. Therefore, the execution of one's duties necessitates a high level of cooperation and treating all partners with respect if productive PPP outcomes are to be sustained (Kalpana, 2014a).

\subsection{Strategies for Public Private Partnership Maturity Trajectory}

For countries to register tangible PPP transitioning, their governments need to: develop sound PPP frameworks aligned to project lifecycle processes; understand and use appropriately the existing PPP innovations across the global to hedge against negative risk impacts; develop PPP projects that fit with in their countries' operational situation and development needs; and put to good use the previously underutilised and undervalued resources such as land and buildings to secure funds for developing new public facilities.

\subsection{Strategies for Risk Management}

Strategies have been dissected into specific and generic categories.

\subsubsection{Specific Strategies}

These relate to key risk management mechanisms for PPP projects discussed in subsection 3.5.1.

\subsubsection{Public private partnership forms}

PPP forms become suitable tools for PPP risk management by: Matching PPP forms inherent characteristics against the existing and/or anticipated operating environment conditions. Using them to develop comprehensive project risk lists and to document their likelihood of occurrence and the magnitude of their impact on project objectives. Utilising them as one of the yardsticks to develop and propose workable risk management practices and to provide guidance on how risk performance reviews should be carried out and corrective actions taken.

\subsubsection{Guarantees}

The public sector can improve risk management through guarantees by: Creating a reserve fund to meet guarantee obligations as they fall due (Aldrete, et al., 2010). Incorporating guarantees costs/risks in project budgets and in national government budgets for better accountability and resource facilitation (Irwin, 2007). Charging fees to beneficiaries of guarantees in order to avoid applications for guarantees, especially on trivial matters (Aldrete, et al., 2010); and sharing of guarantees with concessionaires (e.g. partial credit guarantees) and the citizens (e.g. transferring part of the guarantee costs through taxes or user fee increments) (World Bank, 2013). As well as, having sound advisory teams and approval processes to expedite guarantee obligations; and instituting good accounting standards and promoting modern reporting (Irwin, 2007). 


\subsubsection{Renegotiations}

The public sector can effectively manage risks through renegotiations by enforcing renegotiation principles, and measures that prohibit opportunistic behaviour and those that emphasize effective management of renegotiation processes (Marques \& Berg, 2011; Guasch et al., 2014; Perkins, 2013). Prohibitive measures include: having a freeze period for renegotiations, according public entities powers to reject aggressive and reckless bids, PPP laws providing for a 'no alteration clause' in the risk matrix during renegotiation, increasing political costs for accepting renegotiation demands, having higher bid and performance requirements, and encouraging competitive bidding when additional investment on a project have been proposed. Measures for effective management of renegotiation processes include: the PPP Unit playing a greater role in regulating contracts, establishing regulatory frameworks for ensuring transparent renegotiation processes, having a panel of experts to handle renegotiation concerns, having clear jurisdiction over the decision to renegotiate, establishing compensation and conflict resolution guidelines, negotiating for a fixed interest rate for PPP financing, and extending the duration of the contract as adverse economic conditions persist.

Finally, the key principles of handling renegotiations include: preserving the value for money of the contract, all parties must respect the original contract and each of them must provide an account of contract performance, the outcome of the negotiation should not provide any extra-ordinary benefits to any party, the renegotiation results should not change the risk allocation matrix, renegotiations should never be used as a way of correcting errors (ensure you have the right contract first time), and renegotiations should be restricted to outcomes beyond the PPP parties' control and predictability capacity.

\subsubsection{Generic Strategies}

These are in form of uniform and varying strategies. Uniform strategies cut across project activities no matter the prevailing conditions, and these include: risks must be well identified, understood and evaluated by all parties; risks must be allocated to parties with the best capability to control their occurrence; parties must have the technical capability to prevent adverse effects on project outcomes even when risks have occurred; parties must have the financial ability to sustain the consequences of risks or prevent their occurrences; parties must be willing to accept responsibility of risk management; and risks must be allocated timely (Abednego \& Ogunlana, 2006).

While varying strategies must be applied selectively depending on the situation at hand, and these include: risk avoidance-where risky activities are not undertaken (e.g. opting for public procurement); risk prevention-where an action is taken to reduce vulnerabilities (e.g. a consortium borrows in domestic currency to avoid exchange rate risk); risk transfer-where risk is transferred to another party through a contractual arrangement (e.g. minimum traffic guarantees); risk retention-where based on experience risks are allocated to parties with capacity to reduce their negative repercussions (e.g. designs risks for engineers, and policy changes for government); and insurancewhere financial cover is made to guard against any loss that may accrue from a negative outcome (Burger et al., 2009).

\section{Conclusion}

Lack of a solid research and public sector broad thinking about PPP good governance has been a precursor to the limited PPP success globally. In an attempt to address such gaps, this study provides PPP principles, critical success factors, stakeholder management, PPP maturity trends, and risk management as the primary elements of a well governed PPP system. Public private partnership principles provide standards of behaviour expected of PPP actors, and critical success factors provide core activities with in PPP operations where things must be rightly done. Stakeholder management focuses on stakeholder support and involvement in PPP processes, and PPP maturity trajectory emphases creating a robust PPP environment in order to meet a country's social and economic development needs. While, risk management emphases appropriate problem identification, assessment, allocation and management in the entire PPP processes. A critique for each of the aforementioned key PPP good governance elements was conducted, culminating into strategy proposals on how to enhance PPP governance for improved service delivery.

\section{References}

Abednego, M. P., \& Ogunlana, S. O. (2006). Good project governance for proper risk allocation in public-private partnerships in Indonesia. International Journal of Project Management, 24(7), 622-634. https://doi.org/10.1016/j.ijproman.2006.07.010

Aerts, G., Grage, T., Dooms, M., \& Haezendonck, E. (2014). Public-Private Partnerships for the Provision of Port Infrastructure: An Explorative Multi-Actor Perspective on Critical Success Factors. The Asian Journal of Shipping and Logistics, 30(3), 273-298. https://doi.org/10.1016/j.ajsl.2014.12.002 
Aldrete, R. M., Bujanda, A., \& Valdez-Ceniceros, G. A. (2010). Valuing Public Sector Risk Exposure in Transportation Public-Private Partnerships (No. UTCM 08-41-01). Retrieved from $\mathrm{http} / / / \mathrm{utcm} . t a m u . e d u / p u b l i c a t i o n s /$ final_reports/Aldrete_08-41-01.pdf

Alexander, R. (2013). The public management of Public Private Partnerships. US city-level structures for brownfield clean up and redevelopment. In Greve, C., \& Hodge, G. (Eds.), Rethinking Public Private Partnerships: Strategies for turbulent times (pp. 148-165). Routledge: Critical Studies in Public Management.

Alfen, H. W., Kalidindi, S. N., Ogunlana, S., Wang, S., Abednego, M. P., Frank-Jungbecker, A., ... Zhao, G. (2009). Public-private partnership in infrastructure development: case studies from Asia and Europe. Weimar: Verlag der Bauhaus-Universität.

Alinaitwe, H., \& Ayesiga, R. (2013). Success factors for the implementation of Public-Private Partnerships in the Construction Industry in Uganda. Journal of Construction in Developing Countries, 18(2), 1-14.

Bogdan, R. C., \& Biklen, S. K. (1998). Qualitative research for education: An introduction to theory and methods (2nd ed.). Boston: Allyn and Bacon.

Burger, P., Tyson, J., Karpowicz, I., \& Coelho, M. D. (2009). The effects of the financial crisis on public-private partnerships (Vol. 2144). International Monetary Fund. https://doi.org/10.2139/ssrn.1475389

Casady, C. B., Eriksson, K., Levitt, R. E., \& Scott, W. R. (2019). (Re) defining public-private partnerships (PPPs) in the new public governance (NPG) paradigm: an institutional maturity perspective. Public Management Review, 1-23. https://doi.org/10.1080/14719037.2019.1577909

Chan, A. P. C., Lam, P. T. I., Chan, D. W. M., ASCE, M., Cheung, E., \& Ke, Y. (2010). Critical Success Factors for PPPs in Infrastructure Developments: Chinese Perspective. Journal of Construction Engineering and Management, 36(5). https://doi.org/10.1061/(ASCE)CO.1943-7862.0000152

Cheema, G.S. (2007). Linking Governments and Citizens Through Democratic Governance. In Rondinelli, D. A. (Ed.), Public administration and democratic governance: Governments serving citizens. UN.

De Schepper, S., Dooms, M., \& Haezendonck, E. (2014). Stakeholder dynamics and responsibilities in PublicPrivate Partnerships: A mixed experience. International Journal of Project Management, 32(7), 1210-1222. https://doi.org/10.1016/j.ijproman.2014.01.006

De Vos, A. S. (1998). Research at Grass Roots. A Primer for the Caring Professions. Pretoria: Van Schaik Publishers.

Dechev, D. (2015). Public-Private Partnership - A New Perspective for the Transition Countries. Trakia Journal of Sciences, 13(3), 229. https://doi.org/10.15547/tjs.2015.03.005

Economic and Social Commission for Asia and the Pacific. (2011). A Guidebook on Public-Private Partnership in Infrastructure. United Nations, Bangkok-Thailand.

Eggers, W. D., \& Startup, T. (2006). Closing the infrastructure gap: the role of public-private partnerships. Deloitte.

Felsinger, K. (2011). Public-Private Partnership handbook for Asian Development Bank. Retrieved from http://documents.worldbank.org/curated/en/490511468331774007/Public-Private-Partnership-handbook

Fisher, G., \& Babbar, S. (1996). Private financing of toll roads. Washington, DC: World Bank.

Forrer, J., Kee, J. E., Newcomer, K. E., \& Boyer, E. (2010). Public-private partnerships and the public accountability question. Public Administration Review, 70(3), 475-484. https://doi.org/10.1111/j.15406210.2010.02161.x

Gad, G. M. (2012). Effect of culture, risk, and trust on the selection of dispute resolution methods in international construction contracts. Unpublished doctoral dissertation, Iowa State University.

Gisselquist, R. M. (2012). Good governance as a concept, and why this matters for development policy (No. 2012/30). WIDER Working Paper.

Glaser, M. A. (2007). Networks and Collaborative Solutions to Performance Measurement and Improvement in Sub-Saharan Africa. In Shah, A. (Ed.), Performance Accountability and Combating Corruption. Public Sector Governance and Accountability Series, 1-422. The World Bank 1818 H Street, NW Washington, DC 20433.

Greve, C., \& Hodge, G. (2013). Rethinking Public-Private partnerships. Strategies for turbulent times. Routledge critical studies in Public Management. https://doi.org/10.4324/9780203108130 
Guasch, J. L., Benitez, D., Portabales, I., \& Flor, L. (2014). The Renegotiation of PPP Contracts: An overview of its recent evolution in Latin America.

Hood, J., Fraser, I., \& McGarvey, N. (2006). Transparency of risk and reward in UK public-private partnerships. Public Budgeting \& Finance, 26(4), 40-58. https://doi.org/10.1111/j.1540-5850.2006.00861.x

Infrascope report. (2015). Evaluating the environment for public-private partnerships in Africa. The Economist Intelligence Unit Ltd.

Irwin, T. (2007). Government guarantees: Allocating and valuing risk in privately financed infrastructure projects. World Bank Publications. https://doi.org/10.1596/978-0-8213-6858-9

Kalpana, G. (2014a). Public Private Partnerships. A study in Organizational Design. https://doi.org/10.2139/ssrn.2382648

Kalpana, G. (2014b). Public Private Partnerships. A Comprehensive Survey of Literature.

Klijn, E. H. (2010). Trust in governance networks: Looking for conditions for innovative solutions and outcomes, in Osborne, S.P. The New Public Governance? Emerging perspectives on Theory and practice of public governance. 2601 Australia.

Klijn, E. H., \& Teisman, G. R. (2003). Institutional and strategic barriers to public-private partnership: An analysis of Dutch cases. Public money and Management, 23(3), 137-146. https://doi.org/10.1111/1467-9302.00361

Lammam, C., MacIntyre, H., \& Berechman, J. (2013). Using public-private partnerships to improve transportation infrastructure in Canada.

Li, B., Akintoye, A., Edwards, P. J., \& Hardcastle, C. (2005). Critical success factors for PPP/PFI projects in the UK construction industry. Construction management and economics, 23(5), 459-471. https://doi.org/10.1080/01446190500041537

Liu, J., Love, P. E. D., Smith, J., Regan, M., \& Davis, P. R. (2015). Life Cycle Critical Success Factors for Public Private Partnership Infrastructure Projects. Journal of Management in Engineering, 31(5). https://doi.org/10.1061/(ASCE)ME.1943-5479.0000307

Manrique Millones, G. (2010). Breaking Down Factors of Public-Private Partnership in Urban Rail: Experience from Latin American Cases.

Marques, R. C., \& Berg, S. (2011). Risks, contracts, and private-sector participation in infrastructure. Journal of Construction Engineering and Management, 137(11), 925-932. https://doi.org/10.1061/(ASCE)CO.19437862.0000347

Martin, L., Lawther, W., Hodge, G., \& Greve, C. (2013). Internationally recommended best practices in transportation financing public-private partnerships (P3s). Public Administration Research, 2(2), 15-25. https://doi.org/10.5539/par.v2n2p15

Moore, M., \& Hartley, J. (2010). Innovation in governance. In Osborne, S. P. (Ed.), In The New Public Governance? Emerging perspectives on Theory and practice of public governance.

Muhwezi, M. (2010). Horizontal purchasing collaboration in developing countries: behavioural issues in Public Entities in Uganda. University of Twente.

Mwangi, S. W. (2016). Do Public-Private Partnerships Deliver Value for Money in Infrastructure Projects? A Critical Literature Review. The International Journal of Business \& Management, 4(1), 169.

Nel, D. (2014). International best practice in Public Private Partnerships and Risk Management. Administratio Publica, 22, 2.

O'Toole, L. K., \& Meier, K. J. (2010). Implementation and Managerial Networking in The New Public Governance. In The New Public Governance? Emerging perspectives on the theory and practice of public governance. Routledge: New York and London.

Organisation for Economic Co-operation and Development. (2015). Towards a framework for the governance of infrastructure. Public Governance and Territorial Development Directorate Public Governance Committee.

Osei-Kyei, R. I., \& Chan, A. P. (2015). Review of studies on the Critical Success Factors for Public-Private Partnership (PPP) projects from 1990 to 2013. International Journal of Project Management, 33(6), 13351346. https://doi.org/10.1016/j.ijproman.2015.02.008

Perkins, S. (2013). Better regulation of public-private partnership for transport infrastructure: Summary and 
conclusions. International Transport Forum Discussion Paper.

Pestoff, V., \& Brandsen, T. (2010). Public governance and the third sector: Opportunities for co-production and innovation? In Osborne, S. P. (Ed.), The New Public Governance? Emerging perspectives on Theory and practice of public governance.

Peters, B. G. (2007). Performance-Based Accountability. In Shah, A. (Ed.), Performance Accountability and Combating Corruption. Public Sector Governance and Accountability Series, 1-422. The World Bank 1818 H Street, NW Washington, DC 20433.

Poole, E., Toohey, C., \& Harris, P. (2014). Public infrastructure: a framework for decision-making. Financial Flows and Infrastructure Planning. Sydney: Reserve Bank of Australia.

Public Private Infrastructure Advisory Facility. (2015). Bankability in Highway PPP Projects. The World Bank Group. Retrieved from https://ppiaf.org/documents/3181/download.

Reeves, E. (2013). Mind the gap: Accountability and Value for money in Public-Private Partnerships in Ireland. In Greve, C., \& Hodge, G. (Eds.), Rethinking Public Private Partnerships. Strategies for turbulent times. Routledge Critical Studies in Public Management. https://doi.org/10.4324/9780203108130

Reim, C. (2009). Challenges to Public Private Partnerships. The Example of the London Underground PPPs. Unpublished doctoral dissertation, University of Potsdam.

Rondinelli, D. A. (2007). Governments Serving People: The Changing Roles of Public Administration: In Democratic Governance. In Rondinelli, D. A. (Ed.), Public administration and democratic governance: Governments serving citizens. UN.

Rothballer, C., \& Kim, H. (2013). Strategic Infrastructure Steps to Prepare and Accelerate Public-Private Partnerships. World Economic Forum.

Sako, M. (1992). Price, quality and trust: Inter-firm relations in Britain and Japan (No. 18). Cambridge University Press. https://doi.org/10.1017/CBO9780511520723

Sanda, N. Y., Daniel, M. M., Akande, E. M., \& Adeagbo, D. O. (2016). A Review of Public-Private Partnership for Building and Infrastructure Procurement in Nigeria.

Sarmento, J. M., \& Renneboog, L. (2016). Anatomy of public-private partnerships: their creation, financing and renegotiations. International Journal of Managing Projects in Business, 9(1), 94-122. https://doi.org/10.1108/IJMPB-03-2015-0023

Siemiatycki, M. (2013). Is there a distinctive Canadian PPP model? Reflections on twenty years of practice. In Second CBS-Sauder-Monash PPP Conference, Vancouver, BC.

Silva, S., \& Schaltegger, S. (2019). Social assessment and management of conflict minerals: a systematic literature review. Sustainability Accounting, Management and Policy Journal, 10(1), 157-182. https://doi.org/10.1108/SAMPJ-02-2018-0029

Sundaram, J. K., Chowdhury, A., Sharma, K., \& Platz, D. (2016). Public-Private Partnerships $\quad$ and the 2030 Agenda for Sustainable Development: Fit for purpose? (No. 148): 1-28.

Thieriot, H., \& Dominguez, C. (2015). Public-private partnerships in China: on 2014 as a landmark year, with past and future challenges. International Institute for Sustainable Development, Canada.

Tsukada, S. (2009). Global Experiences of Public Private Partnership for Highway Development.

U.S. Department of Transport. (2016). Successful Practices for P3s. A review of what works when delivering transportation via public-private partnerships.

United Nations Economic Commission for Europe. (2004). Governance in Public Private Partnerships for Infrastructure Development. United Nations, Geneva.

Van Doeveren, V. (2011). Rethinking good governance: Identifying common principles. Public Integrity, 13(4), 301-318. https://doi.org/10.2753/PIN1099-9922130401

Vangen, S., \& Huxham, C. (2010). Introducing the Theory of Collaborative advantage. In Osborne, S. P. (Ed.), The New Public Governance? Emerging perspectives on the theory and practice of public governance. Routledge: New York and London.

Willems, T., Van Dooren, W., \& van den Hurk, M. (2017). PPP policy, depoliticisation, and anti-politics. Partecipazione e conflitto, 10(2), 448-471. 
World Bank Group. (2012). Support to Public-Private Partnerships. Lessons from Experience in Client Countries, FY02-12. Independent Evaluation Group.

World Bank Group. (2016). The State of PPPs. Infrastructure Public-Private Partnerships in Emerging Markets \& Developing Economies 1991-2015.

World Bank. (2013). An Operational Framework for Managing Fiscal Commitments from Public-Private Partnerships: The Case of Ghana. Washington, D.C.

Xu, R. Y., Sun, Q. G., \& Si, W. (2015). The Third Wave of Public Administration: The New Public Governance. Canadian Social Science, 11(7), 11-21.

Yong, H. K. (Ed.). (2010). Public-private partnerships policy and practice: A Reference guide. Commonwealth Secretariat.

Yousaf, M., Ihsan, F., \& Ellahi, A. (2016). Exploring the impact of good governance on citizens' trust in Pakistan. Government Information Quarterly, 33(1), 200-209. https://doi.org/10.1016/j.giq.2015.06.001

Ysa, T., Esteve, M., \& Longo, F. (2013). Enhancing innovation in public organisations through PPPS. The role of public managers. In Greve, C., \& Hodge, G. (Eds.), Rethinking Public-Private Partnership. Routledge Critical Studies in Public Management.

\section{Copyrights}

Copyright for this article is retained by the author(s), with first publication rights granted to the journal.

This is an open-access article distributed under the terms and conditions of the Creative Commons Attribution license (http://creativecommons.org/licenses/by/4.0/). 